\title{
ANALYSIS OF SELECTION INDICATORS OF Badminton Players By The Delphi Method ANd Analytic Hie Rarchy Process
}

\author{
Han-Chen Huang ${ }^{1}$, Chun-Ta Lin $^{2^{*}}$, Chia-Sen $\mathrm{Hu}^{3}$ \\ ${ }^{1}$ Department of Tourism and MICE, Chung Hua University,Taiwan \\ $2 *$ Corresponding AuthorDepartment of Information Management, Yu Da University of \\ Science and Technology, Taiwan \\ ${ }^{3}$ Department of Information Management, Yu Da University of Science and Technology, \\ Taiwan \\ ${ }^{3}$ Guang Hua Junior High School, Hsinchu City, Taiwan.
}

\begin{abstract}
This study aims to clarify the selection standard of potential badminton players and construct an evaluation model of badminton players. Through literature review and the Delphi Method, this study validated the selection indicators of badminton team players: body type, physical qualities, physical functions, psychological qualities, and intelligence level, including a total of 17 detailed indicators. The researcher then interviewed badminton coaches and applied Analytic Hierarchy process (AHP) to determine the importance of the indicators of potential badminton players for badminton coaches. A selection model of badminton players was constructed. The results can serve as reference for badminton coaches' scientific and objective selection of players.
\end{abstract}

\section{KEYWORDS}

Delphi Method, Analytic Hierarchy process, Selection model

\section{INTRODUCTION}

Badminton is a technique-oriented sport, and badminton racquets are important keys. Striking a ball with force requires elegant and delicate techniques, which must be constructed and delivered through precise basic skills, powerful strength, and coordination [1,2]. Badminton is a sport with complicated skills. Selection and training of players should be based on precise and reasonable scientific methods [3-5]. Horng [6] and Chi [7] suggested that when selecting badminton talents, there should be systematic, planned, and organized cultivation of objectives, in order to screen potential badminton players and enhance training performance. How to find excellent badminton talents by scientific and efficient methods is an important issue in badminton development in Taiwan.

This study aims to clarify the selection indicators of potential badminton players in order to establish a selection model for badminton players. Through literature review, the Delphi Method, and AHP, this study validates the important selection indicators of badminton players. The findings are expected to enhance selection precision, and serve as scientific and objective reference for badminton coaches. The research purposes are as follows: 
International Journal of Computer Science \& Information Technology (IJCSIT) Vol 7, No 1, February 2015

1. To clarify the evaluation standard of the selection of badminton talents.

2. To analyze importance of selection indicators of badminton players.

3. To construct a scientific and objective selection model for badminton players.

\section{LITERATURE REVIEW}

\subsection{Selection of sports talents}

Talent selection is the first step of sports training. In order to result in excellent sports performance, besides scientific training, natural talents of sports should be discovered as early as possible. By training from childhood, excellent players will demonstrate better results [5-7]. Selection of athletes is originated from the Olympic Games in Amsterdam, the Netherlands, in 1928. At the time, the host reorganized the athletes' basic information, such as height, weight, date of birth, etc. According to the statistical results of sports scientific researchers, the potential talents were selected based on the characteristics and requirements of different sports items, and a selection model was constructed [8]. This breakthrough immediately enhances the level of the game, as it not only saves labor, materials, and time, but also allows coaches to establish athletes' regular training plans according to the differences of sports. Hence, sports training will be more effective. Selection of sports talents in Taiwan was originated from the 1950s, and in the 1980s, scientific selection was developed; however, research on scientific selection was not conducted until later. Based on literature regarding the selection of athletes in Taiwan, scientific selection was based on "figure, genes, family health history, pathological examination, physical function, and basic physical competence" [5-8]. Hsu [9] indicated that scientific selection of sports talents should include figures and body type, physical function, physical conditions, analysis of sports techniques, creative movement, psychological quality, and intellectual capability. By scientific theory, and through observation, testing, and judgment, young people in excellent condition are selected for systematic and organized training.

Since badminton is based on complicated techniques, how to find more talents through scientific and efficient selection is an important issue for the development of badminton. Regarding scientific selection of sports talents, Chi [7] suggested (1) investigation; (2) survey; (3) experiment; (4) experience; Chou [8] indicated selection by (1) genes; (2) instruments; (3) body types; (4) mental and intellectual functions. According to Chou [8], Bacon [10, 11] and Hellebrandt [12] , selection is based on 5 steps: (1) health examination; (2) test of indicators; (3) comparison of peak of growth and duration; (4) trace of measurement; 5) general decisions.

\subsection{Delphi Method}

The Delphi Method is also called expert survey, and its problem is distribution to experts to inquire about their opinions. All experts' opinions are then retrieved and categorized into general opinions $[13,14]$. The experts obtain feedback of the general opinions, their views are collected again. The opinions are then revised and reorganized. Thus, decisions with more consistent prediction results are progressively obtained.

The method is universal, thus, experts do not have direct discussion or horizontal contact. By repeated inquiry, generation, and revision, the experts finally reach a consensus [15].

The Delphi Method can be adopted to solve complicated problems, such as prediction of population, operation, demand, and education. In addition, it can be used for assessment, decision-making, management communication, and planning. Application of the Delphi Method is based on the following 5 rules [16-18]: 
1. Anonymity: all experts and scholars express their opinions individually, they are strictly anonymous, and their identity is confidential.

2. Iteration: the host collects and announces the participants' opinions. After several rounds, participants can revise their original judgment by reviewing others' data.

3. Controlled feedback: participants are invited to respond to the designed questionnaire, and have total measurement on collective judgment.

4. Statistical group response: general judgment of all participants' opinions usually depends on median, dispersion, and frequency distribution.

5. Expert consensus: the Delphi Method aims to lead to experts' common consensus to have final results.

\subsection{Analytic Hierarchy Process}

AHP is a theory developed by Thomas L. Saaty at the University of Pittsburgh, U.S.A. in 1971. By 1980, AHP became more complete [19-23]. It can be used to solve complicated decisions and factors in uncertain situations, and resolve issues with several criteria, thus, it deals with decision-making.

The content of AHP is to systematically develop a hierarchy of problems. Through pairwise comparison, it determines the relative weights between elements, and develops rankings of the plans as reference to select the best plan [19, 20]. The purpose of AHP is to systemize complicated problems and reorganize related data, thoughts, and intuitive judgments, through logic and a hierarchical structure. For decision makers, the hierarchical structure helps understand the issues, and complicated and non-structural situations are divided into different parts, thus, hierarchical order is established. The values are based on the importance of variables, as determined through subjective judgment. After a series of judgments and statistics, the ranking of variables is established to result in decision makers' conclusions [23-25].

\section{RESEARCH Method AND PROCESS}

\subsection{Research Method}

This study aims to explore the selection indicators of badminton players, as well as the importance of the indicators, in order to establish a new selection decision-making model of badminton players by AHP as reference for badminton coaches to cultivate players. By literature review, this study generalized the selection indicators, and developed an evaluation framework and criteria to select badminton players. The selection model was divided into three levels: objective level, major criteria level, and sub-criteria level. The primary framework was based on repeated questionnaire survey, conducted through the Delphi Method. Finally, this study obtained a complete assessment framework with experts' and scholars' consistent opinions (Figure 1). The hierarchical framework includes three levels, the first level is research purpose; the second level is major criteria, including body type, physical quality, physical function, psychological quality, and intelligence level, and the third level is sub-criteria, including 17 items. 
International Journal of Computer Science \& Information Technology (IJCSIT) Vol 7, No 1, February 2015

\begin{tabular}{|c|c|c|}
\hline Objective & Major criteria & Sub-criteria \\
\hline \multirow{5}{*}{$\begin{array}{c}\text { Selection } \\
\text { of } \\
\text { badminton } \\
\text { players }\end{array}$} & Body type & $\begin{array}{ll}- & \text { Height } \\
- & \text { Figure } \\
\text { - } & \text { Length of arm }\end{array}$ \\
\hline & Physical quality & $\begin{array}{ll}\text { - } & \text { Speed } \\
\text { - } & \text { Reaction } \\
\text { - } & \text { Bounce } \\
\text { - } & \text { Muscular endurance } \\
\text { - } & \text { Flexibility }\end{array}$ \\
\hline & Physical function & $\begin{array}{ll}- & \text { Cardiopulmonary function } \\
\text { - } & \text { Body fat } \\
\text { - } & \text { Eyesight }\end{array}$ \\
\hline & Psychological quality & $\begin{array}{ll}\text { - } & \text { Active } \\
\text { - } & \text { High concentration } \\
\text { - } & \text { Emotion management }\end{array}$ \\
\hline & Intelligence level & $\begin{array}{ll} & \text { Intelligence assessment } \\
\text { - } & \text { Strategy comprehension and application } \\
\text { - } & \text { Immediate reaction }\end{array}$ \\
\hline
\end{tabular}

Figure 1. Hierarchical framework of selection indicators of badminton players

By hierarchical analysis, complicated problems are simplified from top to bottom; and any selection that cannot be presented is quantified in order to easily understand it, develop the ranking of assessment, and enhance decision-making quality. After designing a "questionnaire of hierarchical analysis of weights for the selection indicators of badminton players", this study invites experts and scholars with practical experience in sports circles, and related academic fields, to clarify and validate the weights of the indicators. Huizingh and Vrolijk proposed 9 phases of hierarchical analysis [26], as shown in Figure 2. Phase 7: Comparison of criteria pairwise is shown, as follows [19-23]:

\section{Construction of Pairwise Comparison Matrix:}

It assumes that there are elements $A_{1}, A_{2}, A_{3}, A_{4} \ldots A_{n}$ at a certain level. The weights of elements are $W_{1}, W_{2}, W_{3} \ldots W_{n}$ to construct Pairwise Comparison Matrix. The relative importance of pair $A_{i}$ and $A_{j}$ is as shown by $a_{i j}$. The Pairwise Comparison Matrix of elements $W_{n}, A_{1}, A_{2}, A_{3}, A_{4} \ldots A_{n}$ is $\mathrm{A}=\left\lfloor a_{i j}\right\rfloor$. When weights $W_{1}, W_{2}, W_{3} \ldots W_{n}$ are known, the Pairwise Comparison Matrix $\mathrm{A}=\left\lfloor a_{i j}\right\rfloor$ can be shown by Eq. 1 .

$$
\mathrm{A}=\left\lfloor a_{i j}\right\rfloor=\left[\begin{array}{cccc}
W_{1} / W_{1} & W_{1} / W_{2} & \ldots & W_{1} / W n \\
W_{2} / W_{1} & W_{2} / W_{2} & \ldots & W_{2} / W_{n} \\
\cdot & \cdot & \ldots & . \\
W_{n} / W_{1} & W_{n} / W_{2} & \ldots & W_{n} / W_{n}
\end{array}\right]
$$


International Journal of Computer Science \& Information Technology (IJCSIT) Vol 7, No 1, February 2015

$$
a_{i j}=W_{i} / W_{j}, a_{j i}=W_{j} / W_{i}, \mathrm{i}, \mathrm{j}=1,2, \ldots \mathrm{n} .
$$

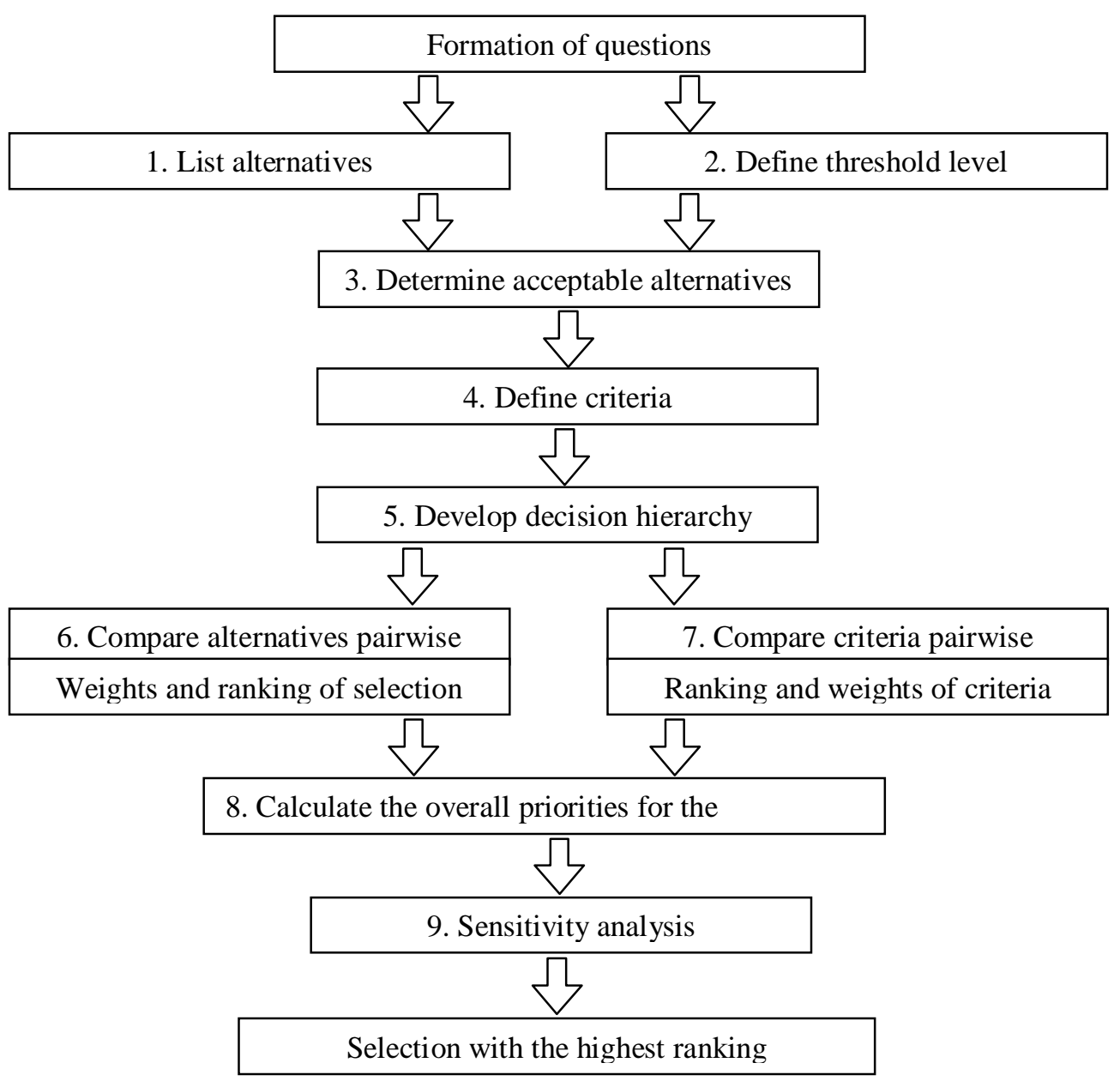

Figure 2. Nine phases of AHP

2. Acquisition of maximum eigen vector and eigenvalue:

According to the Pairwise Comparison Matrix, we obtain the corresponding eigen vector of the maximum eigenvalue or priority vector and weight distribution. Vector $\bar{W}$ of multiplication between Pairwise Comparison Matrix A and weights of indicators is as shown by Eq. 2:

$$
A \bar{W}=\left[\begin{array}{cccc}
\bar{W}=\left(W_{1}, W_{2}, W_{3}, \ldots \ldots W_{n}\right)^{T} \\
W_{1} / W_{1} & W_{1} / W_{2} & \ldots & W_{1} / W_{n} \\
\cdot & W_{2} / W_{2} & \ldots & W_{2} / W_{n} \\
W_{n} / W_{1} & W_{n} / W_{2} & \ldots & W_{n} / W_{n}
\end{array}\right]\left[\begin{array}{c}
W_{1} \\
W_{2} \\
\cdot \\
W_{n}
\end{array}\right]=\lambda\left[\begin{array}{c}
W_{1} \\
W_{2} \\
\cdot \\
W_{n}
\end{array}\right]
$$

According to Eq. 2, multiplication between Pairwise Comparison Matrix A and $\bar{W}$ is equal to 
multiplication between $\lambda$ and $\bar{W} ; A \bar{W}=\lambda \bar{W} \cdot \lambda$ is the eigenvalue of $\mathrm{A}$. It is the corresponding eigen vector of the eigenvalue of Pairwise Matrix A. In pairwise comparison, since $a_{i j}$ is acquired by subjective judgment, it is different from the actual $W_{i} / W_{j}$ and it becomes $a_{i j} \approx W_{i} / W_{j}$. When $a_{i j}$ changes slightly, the eigenvalue will also change. When the eigenvalue is not equal to $\lambda, \lambda$ is the major eigenvalue and is close to the eigenvalue of the theoretical weight. Thus, $\lambda_{\max }$ replaces $\lambda$, as shown in Eq. 3

$$
A \bar{W}=\lambda_{\max } \times \bar{W}
$$

Calculation of maximum eigenvalue $\lambda_{\max }$ is as shown below. Pairwise Comparison Matrix A multiplied eigen vector $\bar{W}$ will be new vector $\bar{W}$, as shown in Eqs. 4 and 5 .

$$
\begin{gathered}
A \bar{W}=\bar{W}^{\prime} \\
{\left[\begin{array}{cccc}
W_{1} / W_{1} & W_{1} / W_{2} & \ldots & W_{1} / W_{n} \\
W_{2} / W_{1} & W_{2} / W_{2} & \ldots & W_{2} / W_{n} \\
\cdot & \cdot & \ldots & \cdot \\
W_{n} / W_{1} & W_{n} / W_{2} & \ldots & W_{n} / W_{n}
\end{array}\right]\left[\begin{array}{c}
W_{1} \\
W_{2} \\
\cdot \\
W_{n}
\end{array}\right]=\left[\begin{array}{c}
W_{1^{\prime}} \\
W_{2^{\prime}} \\
\cdot \\
W_{n^{\prime}}
\end{array}\right]}
\end{gathered}
$$

Vectors obtained are divided by the original vector, and the mean of the total is $\lambda_{\max }$, as shown in Eq. 6.

$$
\lambda_{\max }=\frac{1}{n}\left(\frac{W_{1}}{W_{1}}+\frac{W_{2}}{W_{2}}+\ldots .+\frac{W_{n}^{\prime}}{W_{n}}\right)
$$

\section{Consistency testing:}

It is difficult to require subjects' consistency in pairwise comparison; thus, we must conduct consistency testing to obtain Consistency Index (C.I.) in order to determine if the Pairwise Comparison Matrix of the subjects' responses is a consistency matrix. According to the suggestion of Saaty [21, 22], when C.I. $=0$, it means that the assessment is consistent; and C.I. $\leq$ 0.1 is an acceptable error. Hence, consistency is validated, as shown in Eq. 7.

$$
\text { C.I. }=\frac{\lambda_{\max }-\lambda}{n-1}
$$

According to the Positive Reciprocal matrix developed by scale 1 9; C.I. with different hierarchical numbers is Random Index (R.I.) [21, 22]. The ratio of C.I. and R.I. of a matrix with the same number of hierarchy is called C.R.(Consistence Radio), as shown in Eq. 8. Saaty [21, 22] suggested that when C.R. $\leq 0.1$, consistency is acceptable.

$$
\text { C.R. }=\frac{C . I .}{R . I .}
$$

\subsection{Subjects}

This study treats sports team coaches in Taiwan as questionnaire subjects (a total of 16), including 4 university and college experts and scholars, 3 badminton coaches of senior high school, 3 badminton team coaches of junior high school, 2 badminton coaches of elementary 
International Journal of Computer Science \& Information Technology (IJCSIT) Vol 7, No 1, February 2015

school, and 4 professional badminton coaches (Table 1):

Table 1. Number and percentage of experts

\begin{tabular}{ccc}
\hline Category of experts & Number of experts & Percentage \\
\hline Badminton team coaches of university & 4 & $25 \%$ \\
Badminton coaches of senior high school & 3 & $18.75 \%$ \\
Badminton team coaches of junior high & 3 & $18.75 \%$ \\
school & 2 & $12.5 \%$ \\
Badminton coaches of elementary school & 4 & $25 \%$ \\
Professional badminton coaches & 16 & $100 \%$ \\
\hline Total &
\end{tabular}

\section{RESEARCH RESULTS AND DISCUSSION}

\subsection{Consistency testing}

This study examined the weights of the selection indicators of badminton players by AHP. It determined current badminton coaches' tendency to select talents. The pair comparisons of AHP must satisfy the relationship of priority and intensity. However, in the processes, some factors might cause errors, and consistency testing should be conducted. Thus, Satty [21, 22] suggested testing the consistency of the Pairwise Comparison Matrix by Consistence Index and Consistence Ratio (Table 4-1). In this study, there are 16 questionnaire subjects, including 16 questionnaires retrieved. However, 2 questionnaires failed to pass consistency testing. The results of consistency testing are as shown in Table 2.

Table 2. Result of consistency test

\begin{tabular}{|c|c|c|c|c|c|c|}
\hline Objective & Major criteria & C.I. & C.R. & Sub-criteria & C.I. & C.R. \\
\hline \multirow{16}{*}{$\begin{array}{l}\text { Selection } \\
\text { of } \\
\text { badminton } \\
\text { players }\end{array}$} & & \multirow{16}{*}{0.0635} & \multirow{16}{*}{0.0567} & Height & & \\
\hline & Body type & & & Figure & 0.0197 & 0.0339 \\
\hline & & & & Length of arm & & \\
\hline & & & & Speed & & \\
\hline & & & & Reaction & & \\
\hline & Physical quality & & & Bounce & 0.0431 & 0.0385 \\
\hline & & & & Muscular endurance & & \\
\hline & & & & Flexibility & & \\
\hline & & & & Cardiopulmonary function & & \\
\hline & Physical function & & & Body fat & 0.0566 & 0.0977 \\
\hline & & & & Eyesight & & \\
\hline & & & & Active & & \\
\hline & Psychological & & & High concentration & 0.0343 & 0.0591 \\
\hline & & & & Emotion management & & \\
\hline & & & & Intelligence assessment & & \\
\hline & Intelligence level & & & $\begin{array}{l}\text { Strategy comprehension and } \\
\text { application } \\
\text { Immediate reaction }\end{array}$ & 0.0200 & 0.0344 \\
\hline
\end{tabular}


International Journal of Computer Science \& Information Technology (IJCSIT) Vol 7, No 1, February 2015

\subsection{Analysis of weights}

\subsubsection{Weights of major criteria}

Major criteria include five dimensions. Calculation by Pairwise Comparison Matrix in Table 3 can lead to the weights of the 5 dimensions of the major criteria (Table 4). In the major criteria, the order of importance of the dimensions is, as follows: physical quality (0.335), body type (0.216), physical function (0.197), intelligence level (0.146), and psychological quality (0.107). Importance of these 5 dimensions is significantly different. The physical quality of current players is more important for professional coaches. The effects of "intelligence level" and "psychological quality" in the selection are insignificant. Individuals' physical quality, body type, and physical function are more important.

Table 3. Pairwise Comparison Matrix of major criteria

\begin{tabular}{cccccc}
\hline & Body type & $\begin{array}{c}\text { Physical } \\
\text { quality }\end{array}$ & $\begin{array}{c}\text { Physical } \\
\text { function }\end{array}$ & $\begin{array}{c}\text { Psychological } \\
\text { quality }\end{array}$ & $\begin{array}{c}\text { Intelligence } \\
\text { level }\end{array}$ \\
\hline Body type & 1.000 & 1.034 & 1.168 & 1.715 & 1.140 \\
Physical quality & 0.967 & 1.000 & 3.072 & 4.143 & 1.539 \\
Physical function & 0.856 & 0.326 & 1.000 & 1.905 & 2.267 \\
Psychological quality & 0.583 & 0.241 & 0.525 & 1.000 & 0.949 \\
Intelligence level & 0.877 & 0.650 & 0.441 & 1.053 & 1.000 \\
\hline
\end{tabular}

Table 4. Weights of major criteria

\begin{tabular}{ccccccc}
\hline & Body type & $\begin{array}{c}\text { Physical } \\
\text { quality }\end{array}$ & $\begin{array}{c}\text { Physical } \\
\text { function }\end{array}$ & $\begin{array}{c}\text { Psychologica } \\
\text { 1 quality }\end{array}$ & $\begin{array}{c}\text { Intelligence } \\
\text { level }\end{array}$ & weights \\
\hline Body type & 0.233 & 0.318 & 0.188 & 0.175 & 0.165 & 0.216 \\
Physical quality & 0.226 & 0.308 & 0.495 & 0.422 & 0.223 & 0.335 \\
Physical function & 0.200 & 0.100 & 0.161 & 0.194 & 0.329 & 0.197 \\
Psychological quality & 0.136 & 0.074 & 0.085 & 0.102 & 0.138 & 0.107 \\
Intelligence level & 0.205 & 0.200 & 0.071 & 0.107 & 0.145 & 0.146 \\
\hline
\end{tabular}

\subsubsection{Weights of sub-criteria}

(1) Body type

The sub-criterion includes 3 items. Calculation by Pairwise Comparison Matrix in Table 5 can result in the weights of the sub-criteria (Table 6). Ranking of importance is shown, as follows: height (0.454), figure (0.326), and length of arm (0.220).

Table 5. Pairwise Comparison Matrix of sub-criteria of body type

\begin{tabular}{cccc}
\hline & Height & Figure & Length of arm \\
\hline Height & 1.000 & 1.706 & 1.705 \\
Figure & 0.586 & 1.000 & 1.809 \\
Length of arm & 0.587 & 0.553 & 1.000 \\
\hline
\end{tabular}


International Journal of Computer Science \& Information Technology (IJCSIT) Vol 7, No 1, February 2015

Table 6. Sub-criteria weight of body type

\begin{tabular}{ccccc}
\hline & Height & Figure & Length of arm & weights \\
\hline Height & 0.460 & 0.524 & 0.378 & 0.454 \\
Figure & 0.270 & 0.307 & 0.401 & 0.326 \\
Length of arm & 0.270 & 0.170 & 0.222 & 0.220 \\
\hline
\end{tabular}

(2) Physical quality

The sub-criterion includes 5 items. Calculation by Pairwise Comparison Matrix of Table 7 can result in the weights of the sub-criteria (Table 8). Ranking of importance is shown, as follows: reaction (0.283), speed (0.230), flexibility (0.182), bounce (0.153), and muscular endurance $(0.151)$.

Table 7. Sub-criteria Pairwise Comparison Matrix of physical quality

\begin{tabular}{cccccc}
\hline & Speed & Reaction & Bounce & $\begin{array}{c}\text { Muscular } \\
\text { endurance }\end{array}$ & Flexibility \\
\hline Speed & 1.000 & 1.392 & 0.962 & 1.190 & 1.352 \\
Reaction & 0.719 & 1.000 & 2.714 & 1.619 & 1.171 \\
Bounce & 1.040 & 0.368 & 1.000 & 1.171 & 0.971 \\
Muscular endurance & 0.840 & 0.618 & 0.854 & 1.000 & 0.891 \\
Flexibility & 0.739 & 0.854 & 1.029 & 1.122 & 1.000 \\
\hline
\end{tabular}

Table 8. Sub-criteria weights of physical quality

\begin{tabular}{ccccccc}
\hline & Speed & Reaction & Bounce & $\begin{array}{c}\text { Muscular } \\
\text { endurance }\end{array}$ & Flexibility & weights \\
\hline Speed & 0.231 & 0.329 & 0.147 & 0.195 & 0.251 & 0.230 \\
Reaction & 0.166 & 0.236 & 0.414 & 0.265 & 0.217 & 0.283 \\
Bounce & 0.240 & 0.087 & 0.152 & 0.192 & 0.180 & 0.153 \\
Muscular endurance & 0.194 & 0.146 & 0.130 & 0.164 & 0.165 & 0.151 \\
Flexibility & 0.170 & 0.202 & 0.157 & 0.184 & 0.186 & 0.182 \\
\hline
\end{tabular}

(3) Physical function

The sub-criterion includes 3 items. Calculation by Pairwise Comparison Matrix in Table 9 can result in the weights of the sub-criteria (Table 10). Ranking of importance is as follows: cardiopulmonary function (0.693), body fat (0.186), and eyesight (0.121).

Table 9. Sub-criteria Pairwise Comparison Matrix of physical function

\begin{tabular}{cccc}
\hline & $\begin{array}{c}\text { Cardiopulmonary } \\
\text { function }\end{array}$ & Body fat & Eyesight \\
\hline Cardiopulmonary & 1.000 & 5.510 & 4.367 \\
function & 0.181 & 1.000 & 2.143 \\
Body fat & 0.229 & 0.467 & 1.000 \\
Eyesight & & \\
\hline
\end{tabular}


International Journal of Computer Science \& Information Technology (IJCSIT) Vol 7, No 1, February 2015

Table 10. Sub-criteria weights of physical function

\begin{tabular}{ccccc}
\hline & $\begin{array}{c}\text { Cardiopulmonary } \\
\text { function }\end{array}$ & Body fat & Eyesight & weights \\
\hline Cardiopulmonary & 0.709 & 0.790 & 0.582 & 0.693 \\
function & 0.129 & 0.143 & 0.285 & 0.186 \\
Body fat & 0.162 & 0.067 & 0.133 & 0.121 \\
Eyesight & & & & \\
\hline
\end{tabular}

(4) Psychological quality

The sub-criterion includes 3 items. Calculation by Pairwise Comparison Matrix in Table 11 can result in the weights of the sub-criteria (Table 12). Ranking of importance is as follows: high concentration (0.444), active (0.319), and emotion management (0.237).

Table 11. Sub-criteria Pairwise Comparison Matrix of psychological quality

\begin{tabular}{cccc}
\hline & Active & High concentration & Emotion management \\
\hline Active & 1.000 & 0.925 & 1.043 \\
High concentration & 1.081 & 1.000 & 2.467 \\
Emotion management & 0.958 & 0.405 & 1.000 \\
\hline
\end{tabular}

Table 12. Sub-criteria weights of psychological quality

\begin{tabular}{ccccc}
\hline & Active & $\begin{array}{c}\text { High } \\
\text { concentration }\end{array}$ & $\begin{array}{c}\text { Emotion } \\
\text { management }\end{array}$ & weights \\
\hline Active & 0.329 & 0.397 & 0.231 & 0.319 \\
High concentration & 0.356 & 0.429 & 0.547 & 0.444 \\
Emotion management & 0.315 & 0.174 & 0.222 & 0.237 \\
\hline
\end{tabular}

(5) Intelligence level

The sub-criterion includes 3 items. Calculation by Pairwise Comparison Matrix in Table 13 can result in the weights of the sub-criteria (Table 14). Ranking of importance is, as follows: strategy comprehension and application (0.465), intelligence assessment (0.336), and immediate reaction $(0.199)$.

Table 13. Sub-criteria Pairwise Comparison Matrix of intelligence level

\begin{tabular}{cccc}
\hline & $\begin{array}{c}\text { Intelligence } \\
\text { assessment }\end{array}$ & $\begin{array}{c}\text { Strategy } \\
\text { comprehension } \\
\text { and application }\end{array}$ & $\begin{array}{c}\text { Immediate } \\
\text { reaction }\end{array}$ \\
\hline Intelligence assessment & 1.000 & 0.878 & 1.394 \\
Strategy comprehension and application & 1.139 & 1.000 & 2.886 \\
Immediate reaction & 0.718 & 0.347 & 1.000 \\
\hline
\end{tabular}

Table 14. Sub-criteria weight of intelligence level

\begin{tabular}{ccccc}
\hline & $\begin{array}{c}\text { Intelligence } \\
\text { assessment }\end{array}$ & $\begin{array}{c}\text { Strategy } \\
\text { comprehension } \\
\text { and application }\end{array}$ & $\begin{array}{c}\text { Immediate } \\
\text { reaction }\end{array}$ & weights \\
\hline $\begin{array}{c}\text { Intelligence assessment } \\
\text { Strategy comprehension }\end{array}$ & 0.350 & 0.395 & 0.264 & 0.336 \\
$\begin{array}{c}\text { and application } \\
\text { Immediate reaction }\end{array}$ & 0.399 & 0.449 & 0.547 & 0.465 \\
\hline
\end{tabular}


International Journal of Computer Science \& Information Technology (IJCSIT) Vol 7, No 1, February 2015

\subsubsection{Weights and ranking of all criteria}

After the calculation of hierarchical analysis, we can obtain the weights of criteria (Table 15). Ranking of the Top 10 is cardiopulmonary function (0.136), height (0.098), reaction (0.095), speed (0.077), figure (0.070), strategy comprehension and application (0.068), flexibility (0.061), bounce (0.051), muscular endurance (0.051), and intelligence assessment (0.049). The total weight of the 10 indicators is $75.6 \%$. Indicators that are less important: eyesight, emotion management, immediate reaction, active, body fat, high concentration, and length of arm. The total weight of the 7 indicators is only $24.4 \%$.

Table 15. Weights and ranking of selection indicators of badminton players

\begin{tabular}{|c|c|c|c|c|c|c|}
\hline Objective & Major criteria & Weights & Sub-criteria & $\begin{array}{c}\text { Hierarchical } \\
\text { weights }\end{array}$ & $\begin{array}{l}\text { Overall } \\
\text { weights }\end{array}$ & $\begin{array}{l}\text { Overall } \\
\text { ranking }\end{array}$ \\
\hline \multirow{17}{*}{$\begin{array}{l}\text { Selection } \\
\text { of } \\
\text { Badminton } \\
\text { players }\end{array}$} & \multirow{3}{*}{ Body type } & \multirow{3}{*}{0.216} & Height & 0.454 & 0.09801 & 2 \\
\hline & & & Figure & 0.326 & 0.07037 & 5 \\
\hline & & & Length of arm & 0.220 & 0.04760 & 11 \\
\hline & \multirow{5}{*}{ Physical quality } & \multirow{5}{*}{0.335} & Speed & 0.230 & 0.07712 & 4 \\
\hline & & & Reaction & 0.283 & 0.09480 & 3 \\
\hline & & & Bounce & 0.153 & 0.05119 & 8 \\
\hline & & & Muscular endurance & 0.151 & 0.05066 & 9 \\
\hline & & & Flexibility & 0.182 & 0.06094 & 7 \\
\hline & \multirow{3}{*}{$\begin{array}{l}\text { Physical } \\
\text { function }\end{array}$} & \multirow{3}{*}{0.197} & $\begin{array}{l}\text { Cardiopulmonary } \\
\text { function }\end{array}$ & 0.693 & 0.13645 & 1 \\
\hline & & & Body fat & 0.186 & 0.03656 & 13 \\
\hline & & & Eyesight & 0.121 & 0.02377 & 17 \\
\hline & \multirow{3}{*}{$\begin{array}{l}\text { Psychological } \\
\text { quality }\end{array}$} & \multirow{3}{*}{0.107} & Active & 0.319 & 0.03411 & 14 \\
\hline & & & High concentration & 0.444 & 0.04745 & 12 \\
\hline & & & Emotion management & 0.237 & 0.02534 & 16 \\
\hline & \multirow{3}{*}{$\begin{array}{l}\text { Intelligence } \\
\text { level }\end{array}$} & \multirow{3}{*}{0.146} & Intelligence assessment & 0.336 & 0.04897 & 10 \\
\hline & & & $\begin{array}{l}\text { Strategy comprehension } \\
\text { and application }\end{array}$ & 0.465 & 0.06770 & 6 \\
\hline & & & Immediate reaction & 0.199 & 0.02895 & 15 \\
\hline
\end{tabular}

\section{Conclusions}

Scientific selection of badminton players is a complicated and important issue for many badminton coaches in Taiwan. Therefore, by literature review, the Delphi method, and AHP, this study analyzed and constructed a selection model, and determined the indicators and weights of badminton coaches' selection. The proposed a selection model of badminton players can serve as scientific and objective reference for badminton coaches. The selection framework contains 5 dimensions: (1) body type; (2) physical quality; (3) physical function; (4) psychological quality; (5) intelligence level, including 17 items. The top 10 indicators are cardiopulmonary function, height, reaction, speed, figure, strategy comprehension and application, flexibility, bounce, muscular endurance, and intelligence. Importance of the ten indicators achieves $75.6 \%$. 
International Journal of Computer Science \& Information Technology (IJCSIT) Vol 7, No 1, February 2015

\section{ACKNOWLEDGEMENTS}

This study was developed and planned by Dr. Han-Chen Huang and accomplished with the assistance of Chia-Sen Hu. Under the advices of Dr. Chun-Ta Lin, Chia-Sen Hu probed into this research topic and obtained the master's degree.

\section{REFERENCES}

[1] Min, T., (2009) "Pre-competition Training for Teenagers Badminton Athlete", Journal of Hubei Sports Science, Vol. 28, No. 6, pp 722-724.

[2] Chuang, K.S., Liao, W.C., and Lin, W.H., (2009) "Investigation on Multiple-shuttle Training and Psychological Strategy of Badminton”, Journal of Physical Education in Formosa, Vol. 3, No. 1, pp 23-29.

[3] Jou, Y.L., and Lin, Y.C., (2013) "Exploration of Professional Skills and Professional Physical Strength in Badminton", Journal of Physical Education Fu Jen Catholic University, Vol. 12, No. 1, pp 127-136.

[4] Chiu, H.H., (2010) "Comparison of Anthropometrics of the Badminton Athletes of Age 16-18 of Cross-Straight”, College sports academic journal, Vol. 99, No. 1, pp 531-540.

[5] Wu, S.K., Li, Y.C., Chen, W.Y., Wu, S.Y., Song, T.F., Chen, W.Y., and Huang, M.H., (2014) "Assessment of Visual Information Processing Ability in Elite Racket Sport Players", Sports and Exercise Research, 16(2), 226-233, 2014.

[6] Horng, S.J., and Chang, C.M., (2006) "A Confirmatory Factor Analysis of the Test Model of Badminton Footwork on Power", sports and Exercise Research, Vol. 8, No. 2, pp 95-105.

[7] Chi, S.C., Yau, H.D., and Wang, J.C., (2006) "The Relationship between Training Process and Performance in 2004 Olympic Badminton Player", National Sports Institute Forum, Vol. 17, No. 2, pp 93-102.

[8] Chou, T.S., (2011) "Discussion of badminton player selection", Pingtung university sports Journal, Vol. 14, No. 1, pp 436-446.

[9] Hsu, S.Y., (2004) Introduction to Exercise Science, Taiwan Normal University Book.

[10] Bacon, T., (1989) "The planning and integration of mental training programs", Science Periodical on Research and Technology in Sport, Vol. 10, No. 1, pp 1-8.

[11] Bacon, T., (1999) Peridization: theory and methodology of training, Human Kinetics Publisher Inc.

[12] Hellebrandt, F., and Houtz, S., (1956) "Mechanisms of muscle training in man: Experimental demonstration of the overload principle", Physical Therapy Review, Vol. 36, No. 1, pp 371-383.

[13] Hasanzadeh, M., Danehkar, A., and Pak, A., (2012) "Application of Delphi Method for Criteria Selection in Site Survey of Oil Jetties in Iran", Environment and Natural Resources Research, Vol. 2, No. 1, pp 119-128.

[14] Li, T., and Ding, Y., (2013) "Technological Capability Evaluation Model of Marine High-tech Industries in China Based on Borda and Fuzzy Comprehensive Method", Journal of Convergence Information Technology, Vol. 8, No. 1, pp 715- 723.

[15] Chang, C.C., Chao, M.C., Liao, K.H., and Huang, C.Y., (2013) "Development of an Instrument to Measure International Health Tourism in Taiwan: A Customers' Perspective", Advances in Information Sciences and Service Sciences, Vol. 5, No. 9, pp 242-248.

[16] Chang, J., (2004) "Study on the Issue of Taxation of E-Commerce Transaction: An Application of Delphi and AHP", Journal of Business Administration, Vol. 60, No. 1, pp 85-114.

[17] Huang, H.C., (2013) "A Site Assessment Model for Water Recreation Activities", Journal of Convergence Information Technology, Vol. 8, No. 3, pp 286-295.

[18] Shahmiri, F., Shabani, R., Amanpour, N., and Norouzi, N., (2012) "Offering a Model to Identify the Tools to Formulate Innovation Strategy Using Integrating Innovative Capabilities and Decision Making Methods", Research Notes in Information Science, Vol. 9, No. 1, pp 1-11.

[19] Teng, J.Y., and Tzeng, G.H., (1989) "The Analytic Hierarchy Process: Concepts, Techniques and Applications (I)", Journal of the Chinese Statistical Association, Vol. 27, No. 6, pp 5-22.

[20] Teng, J.Y., and Tzeng, G.H., (1989) "The Analytic Hierarchy Process: Concepts, Techniques and Applications (II)", Journal of the Chinese Statistical Association, Vol. 27, No. 7, pp 1-20.

[21] Saaty, T.L., (1980) The analytic hierarchy process: Planning, Priority Setting and Resource Allocation, McGraw-Hill. 
International Journal of Computer Science \& Information Technology (IJCSIT) Vol 7, No 1, February 2015

[22] Saaty, T.L., and Kearns, K.P., (1985) Analytic Planning- The Organization of Systems, International Series in Modern Applied Mathematics and Computer Science 7, Pergamon Press.

[23] Huang, H.C., (2013) "Weight Analysis of Criterion and Sub-Criterion for Supplier Selection", Journal of Next Generation Information Technology, Vol. 4, No. 5, pp 55-62.

[24] Mohammed F.A., and Hagag, M.A.E., (2013) "Integrating AHP and Genetic Algorithm Model Adopted for Personal Selection”, International Journal of Engineering Trends and Technology, Vol. 6, No. 5, pp 247-256.

[25] Zakaria, N.F., Mohamed, H.D., and Razak, A.B., (2010) "Deriving Priority in AHP using Evolutionary Computing Approach", WSEAS transactions on information science and applications, Vol. 7, No.5, pp 714-724.

[26] Huizingh, E.K.R.E., and Vrolijk, H.C.J., (1995) Decision Support for Information Systems Management: Applying Analytic Hierarchy Process, Research Report No. 95B26, University of Groningen. 